\title{
Ketahanmalangan Pengelola PKBM Dalam Mengembangkan Inovasi Pendidikan Nonformal
}

\author{
Devi Merina Tuz Sa'diyah ${ }^{1}$, Ahmad $^{2}$ dan Nilna Sa'adayah ${ }^{3}$ \\ ${ }^{1,3}$ Mahasiswa Jurusan Pendidikan Luar Sekolah Fakultas Ilmu Pendidikan Universitas \\ Negeri Malang, Malang Indonesia \\ ${ }^{2}$ Dosen Jurusan Pendidikan Luar Sekolah Fakultas Ilmu Pendidikan Universitas \\ Negeri Malang, Malang Indonesia \\ *e-mail: merinasadiyah@gmail.com ${ }^{1}$, ahmad.fip@um.ac.id ${ }^{2}$, nilnas1998@gmail.com ${ }^{3}$
}

Received: 26 April 2021; Revised: 16 July 2021; Accepted: 13 August 2021

DOI: http://dx.doi.org/10.37905/aksara.7.3.987-998.2021

\begin{abstract}
The focus of this research is to describe the strategy of adversity quotient for the management of the Community Learning Activity Center (PKBM) to develop innovations in turning barriers into opportunities for non-formal education programs. Qualitative research with this type of case study was carried out at PKBM Mentari, using structured interviews as the primary data collection method, in order to obtain primary data and document matrix methods to obtain secondary data. the data were analyzed using interactive techniques belonging to Miles and Huberman with the stages of data reduction, data presentation and conclusion drawing. The results of this study are the adversity quotient strategy that generally implemented by PKBM is very good, this can be seen from the indicators including: 1) Organizing learning activities flexibly in terms of time, so that it does not interfere with the daily activities of the community; 2) Provide learning at affordable costs so as not to burden the community in participating in learning; 3 ) Making the community the main partner in the continuation of teaching and learning activities at PKBM and 4) Building synergies with local village officials. The relatively short research time is the main limitation in compiling this study, so that it only maximizes the statements of the main informants.
\end{abstract}

Keywords. adversity quotient, PKBM, Nonformal Education

\section{PENDAHULUAN}

Upaya sadar untuk membelajarkan masyarakat demi membangun masyarakat yang berkarakter serta cerdas dan memiliki intelektualitas tinggi merupakan definisi umum dari kata pendidikan. Pendidikan juga disebut sebagai salah satu dari sekian banyak kebutuhan masyarakat yang dipandang penting untuk segera dipenuhi. Pendidikan memiliki banyak sekali definisi, keberagaman definisi tersebut menggambarkan bahwa pendidikan memiliki ranah yang sangat luas serta tanggung jawab yang cukup berat untuk dapat melahirkan generasi yang berkarakter, cerdas serta berbudi luhur. Keberagaman yang menjadi ciri khas masyarakat Indonesia lantas mempengaruhi upaya-upaya pemenuhan kebutuhan belajar masyarakat. Seperti halnya manusia yang mengalami perkembangan serta pertumbuhan fisik secara dinamis, maka pendidikan sebagai kebutuhan masyarakat juga turut serta mengalami perkembangan bahkan perubahan. 
Ketahanmalangan merupakan sebuah kapabilitas seseorang untuk bertahan ditengah permasalahan yang menyulitkan serta menanggulangi permasalahan tersebut dan kemudian dirubah menjadi sebuah peluang. Ketatanmalangan adalah kemampuan seseorang dalam menghadapi kesulitan hidup sehingga menemukan solusi secara tepat sehingga mencapai kesuksesan.(Hesti Ratna Juwita., Roemintoyo, 2020)

Dewasa ini dunia sedang diresahkan oleh pandemi covid-19 (corona virus disease 2019) yang mewabah sekitar dua tahun lalu, tepatnya pada tahun 2019. Pada pertengahan Mei 2021, Komite Penanganan Covid-19 dan Pemulihan Ekonomi Nasioanl (KPCPEN) dalam (https://covid19.go.id) telah mencatat sebanyak 1.748.230 kasus terkonfirmasi dengan angka kematian sekitar 48.477 kasus dan angka kesembuhan sebanyak 1.612.239 kasus. Walaupun data kesembuhan di Indonesia tercatat cukup banyak, akan tetapi tidak dapat dipungkiri bahwa pandemi covid-19 ini seakan melumpuhkan masyarakat di berbagai sektor di seluruh dunia. Mulai dari sektor kesehatan yang porak-poranda dengan lonjakan angka pasien covid-19 serta angka kematian, kemudian sektor ekonomi yang melemah dengan pembatasan sosial yang tidak memungkinkan masyarakat untuk melakukan kegiatan jual-beli secara langsung seperti sebelumnya, adapula sektor keamanan yang turut terpengaruh karena ekonomi yang menurun, selain itu juga terdapat sektor pendidikan yang tidak dapat menyelenggarakan pendidikan secara tatap muka seperti sedia kala. Hari demi hari keadaan seakan semakin tidak terkendali. Demi menanggulangi keadaan yang diambang krisis, maka pemerintah menetapkan kebijakankebijakan baru yang terus diusulkan dan diuji coba dengan harapan dapat meminimalisir penyebaran virus covid-19 serta mengupayakan stabilitas perekonomian masyarakat. (Perbawa, 2021) Setelah dua tahun berjalan, masyarakat masih dituntut untuk terbiasa dengan protokol kesehatan yang harus dipatuhi dalam menjalani kegiatan sehari-hari. Akan tetapi, adaptasi tentu tidak dapat dilaksanakan secara instan, melainkan perlu adanya proses pembiasaan yang dilakukan secara terus-menerus.

Berbagai problematika yang muncul sebagai dampak dari pandemi covid-19 ini juga turut berpengaruh pada sektor pendidikan.(Apriyanti \& Widoyoko, 2021). Adanya pembatasan sosial berskala besar menjadikan pendidikan tidak lagi dapat diselenggarakan secara langsung. Untuk menanggulangi hal ini pemerintah menetapkan bahwa pembelajaran dapat diselenggarakan secara online.(Agustin et al., 2020). Setelah dua tahun berlalu dengan uji coba pembelajaran online, dapat disimpulkan bahwa pembelajaran tersebut kurang efektif, karena prosesnya yang masih asing dengan pelajar Indonesia, kemudian terbatasnya subsidi kuota belajar, terbatasnya media pembelajaran serta tugas-tugas mandiri yang seakan tiada habisnya dari waktu ke waktu. Kondisi ini diperparah dengan adanya situasi yang kurang kondusif sehingga menyebabkan pembelajaran menjadi kurang efektif. Setelah mengalami berbagai kesulitan dalam belajar, akhirnya muncullah ketidakpuasan masyarakat terhadap sistem pembelajaran, khususnya pembelajaran yang diselenggarakan melalui ranah pendidikan formal.

Pendidikan Nonformal sebagai ranah pendidikan yang dikenal dengan ciri fleksibililtasnya, memegang peran penting untuk mewujudkan tujuan pendidikan, salah satunya melalui Pusat Kegiatan Belajar Masyarakat (PKBM) yang dapat menjadi sebuah wadah yang menaungi serta bertanggung jawab dalam mewujudkan pemenuhan berbagai kebutuhan masyarakat dalam sektor pendidikan.(Mochammad Syamsuddin et al., 2015). Demi memenuhi kebutuhan masyarakat dalam sektor pendidikan tersebut, PKBM tentu menghadapi berbagai kesulitan di lapangan, mengingat pendidikan formal masih menjadi 
ranah pendidikan utama yang dikenal akrab oleh masyarakat. Oleh sebab itu, para praktisi pendidikan nonformal, khususnya para pengelola PKBM perlu memiliki kemampuan dalam bertahan dalam menghadapi berbagai kesulitan yang pasti akan hadir, apalagi dalam situasi pandemi seperti saat ini. Seperti pada kesulitan-kesulitan masyarakat dalam mengikuti pembelajaran daring, PKBM dapat mengubah kesulitan tersebut menjadi peluang untuk menambah warga belajarnya dengan menyediakan pembelajaran yang lebih fleksibel.

Pentingnya kajian ini adalah untuk mendeskripsikan bahwa tantangan serta hambatan yang dihadapi oleh praktisi pendidikan nonformal tidak mudah. Oleh sebab itu setiap akademisi pendidikan nonformal perlu memiliki daya tahan yang kuat dalam menghadapi berbagai hambatan serta tantangan yang pasti akan muncul di lapangan sehingga hambatan tersebut dapat ditanggulangi dengan baik dan mewujudkan inovasi pendidikan nonformal.

\section{METODE}

Penelitian ini dilakukan di PKBM Mentari terletak di Jalan Gatot Kaca Nomor H27, Niwin, Sidorahayu, Kecamatan Wagir, Kabupaten Malang dengan pendekatan penelitian kualitatif menggunakan jenis penelitian studi kasus. Penelitian ini bertujuan untuk menganalisa secara mendalam strategi ketahanmalangan PKBM Mentari dalam mengahadapi krisis, khususnya pada era pandemi seperti saat ini. Data dikumpulkan dengan menggunakan teknik wawancara terstruktur, dan analisis dokumen. Penelitian kualitatif merupakan metode naturalistik yang diselenggarakan untuk mengkaji dan menganalisa suatu fenomena yang terjadi melalui subjek penelitian. Data yang diperoleh merupakan gambaran dari situasi asli yang terdapat di lapangan.

Kehadiran peneliti menjadi faktor utama yang diperlukan sebagai pengumpul data utama baik dilakukan secara langsung maupun tidak langsung. Peneliti hadir di lapangan untuk mengamati serta menggali data sebanyak mungkin. Kehadiran peneliti juga dimaksudkan untuk membangun hubungan yang baik, terutama dengan narasumber utama supaya memicu adanya keterbukaan demi mendapatkan data yang terbaik. Data diperoleh dari proses wawancara dengan narasumber yakni pengelola PKBM Mentari, dan warga belajar. Data yag diperoleh kemudian dianalisis menggunakan teknik analisis interaktif milik Miles dan Huberman dengan cara mereduksi data, menyajikan data kemudian penarikan kesimpulan.

\section{HASIL DAN PEMBAHASAN}

PKBM Mentari dirintis sebagai bentuk dari upaya pemenuhan kebutuhan masyarakat melalui ranah pendidikan nonformal dengan beragam program pembelajaran, diantaranya program kesetaraan, program keaksaraan fungsional, program home schooling, program pendidikan anak usia dini, pemberdayaan masyarakat, pelatihan life skill. PKBM Mentari menjadikan kebutuhan masyarakat sebagai tujuan utama dari penyelenggaraan pembelajaran. Oleh sebab itu berbagai kegiatan belajar-mengajar dikemas secara fleksibel mungkin supaya dapat memenuhi kebutuhan masyarakat khususnya para warga belajar secara optimal tanpa mengganggu aktivitas maupun pekerjaan dari warga belajar, mengingat mayoritas warga belajar di PKBM merupakan orang dewasa. 
Hasil penelitian menunjukkan bahwa dalam penyelenggaraan program, selalu ada saja kesulitan yang hadir, diantaranya kesulitan untuk menjaring warga belajar khususnya dalam program kesetaraan. Masyarakat masih belum menyadari betul pentingnya pendidikan, khususnya pendidikan dasar beserta ijazahnya. Hal ini lantas mendorong adanya berbagai penolakan masyarakat untuk mengikuti program kesetaraan yang ditawarkan. Selain itu, biaya operasional pendidikan juga sering kali menjadi salah satu pertimbangan yang memberatkan masyarakat untuk mengikuti kegiatan pembelajaran. Dengan minimnya kesadaran akan pentingnya pendidikan, masyarakat lebih memilih untuk menggunakan uangnya dalam memenuhi kebutuhan serta keinginannya pribadi dari pada untuk mengikuti pembelajaran.

Sebagaimana hasil kajian berdasarkan tanggapan warga belajar, sebelum mengikuti program kesetaraan, warga belajar memandang pendidikan tidak berperan penting dalam kehidupan mereka yang mayoritas berorientasi pada peningkatan ekonomi. Selain itu tidak ada waktu baginya untuk memikirkan mengenai kegiatan sekolah yang ditawarkan, karena menurutnya kegiatan tersebut tidak penting dan justru dapat mengganggu kegiatan yang lebih penting yakni bekerja untuk membantu orangtuanya dalam memenuhi kebutuhan sehari-hari.

Mewabahnya pandemi covid-19 dapat disebut melumpuhkan masyarakat dalam berbagai sektor. Warga belajar berpendapat bahwa selama pandemi ini, pekerjaan yang tersedia sangat minim, sehingga pendapatan yang diperolehpun sangat sedikit. Hal ini menyebabkan waktu beliau terbuang sia-sia karena kebanyakan menganggur, dan mencoba mencari pekerjaan lain akan tetapi mengalami kesulitan karena kualifikasi pendidikan yang mengharuskan pelamar memiliki ijazah SLTA/sederajat sedangkan beliau hanya memiliki ijazah Sekolah Dasar. Hal inilah yang kemudian melatarbelakangi warga belajar secara keseluruhan berpendapat bahwa Pendidikan itu penting dalam kehidupan sebagai modal sosial kehidupan manusia (Asmin, 2018).

Lain halnya dengan pandangan pengelola PKBM bahwa selama pandemi ini PKBM Mentari mendapat warga belajar baru secara kuantitas banyak. Mayoritasnya adalah anak-anak di usia sekolah yang putus sekolah karena tidak sanggup mengikuti sistem pendidikan yang diselenggarakan oleh sekolah formal. Masyarakat beranggapan bahwa pendidikan secara daring tidak efektif karena anak tidak mampu belajar secara optimal melainkan cenderung hanya bermain gadget. Selain itu para wali warga belajar juga harus mengeluarkan biaya tambahan untuk membelikan paket data maupun biaya wifi yang diperlukan dalam pembelajaran daring. Demi menanggulangi hal tersebut maka PKBM menyelenggarakan kegiatan belajar-mengajar dengan sistematika yang dikehendaki oleh para warga belajar. Sesuai dengan karakteristik dari pendidikan nonformal yang ramah serta fleksibel, maka warga belajar memiliki kebebasan untuk menentukan apakah pembelajaran dilaksanakan secara online ataupun tatap muka secara langsung. Mayoritas warga belajar PKBM Mentari menghendaki penyelenggaraan kegiatan belajar-mengajar dengan tatap muka secara langsung, karena warga belajar lebih tertarik dengan proses pembelajaran interaktif di dalam kelas dan merasa kurang nyaman dengan pembelajaran daring. Hal ini mengharuskan pihak PKBM melakukan koordinasi dengan beberapa pihak terkait izin penyelenggaraan pembelajaran secara langsung, antara lain perangkat-perangkat desa khususnya kepala desa, masyarakat sekitar dan satuan tugas penangggulangan covid-19 setempat. 


\section{PEMBAHASAN}

Pada era pandemi covid-19 ini, masyarakat mengalami kesulitan di berbagai sektor kehidupan, tidak terkecuali pada sektor pendidikan. Masyarakat terhimpit dalam batasan-batasan yang diberlakukan untuk meminimalisir resiko penularan virus covid-19. Batasan-batasan tersebut lantas mengharuskan pendidikan formal diselenggarakan secara online. Hal ini ternyata justru memicu berbagai permasalahan, seperti keharusan wali warga belajar untuk membelikan perangkat seluler seperti handphone sebagai salah satu media utama pembelajaran, warga belajar cenderung memanfaatkan gadget untuk bermain game, minimnya pemahaman warga belajar mengenai materi yang disampaikan, tugas-tugas yang diberikan seakan tidak ada habisnya, dan berbagai problematika lain yang mengindikasi ketidak efektifan pembelajaran secara daring. Rendahnya efektifitas pembelajaran ini dianggap tidak sebanding dengan biaya tambahan yang harus dikeluarkan para wali warga belajar untuk membeli kuota internet. Singkatnya, biaya pengeluaran semakin besar akan tetapi warga belajar tidak dapat belajar secara optimal melainkan menambah beban psikis baik pada anak maupun orangtua.

Pada dasarnya pendidikan nonformal dipandang sebagai penambah atau pelengkap pendidikan formal. Akan tetapi, seiring berjalannya waktu, pendidikan nonformal kemudian diakui oleh masyarakat sebagai pengganti pendidikan formal. Ketika pendidikan formal kurang mampu menyediakan sistem pembelajaran yang memuaskan masyarakat, maka pendidikan nonformal dapat menyediakan pembelajaran yang fleksibel dan terjangkau yang dapat disesuaikan dengan kebutuhan serta minat masyarakat. Pada era pembatasan sosial seperti saat ini, pembelajaran dalam ranah nonformal dapat diselenggarakan berdasarkan kehendak warga belajar, sehingga dapat membebaskan warga belajar untuk memberikan pendapat dalam menentukan proses pembelajaran akan diselenggarakan secara online ataupun tatap muka secara langsung. Hal ini menjadi salah satu kekuatan satuan pendidikan nonformal untuk bertahan di tengah krisis yang bermunculan sebagai dampak dari mewabahnya virus covid-19. Walaupun tidak dapat dipungkiri bahwa satuan-satuan pendidikan nonformal juga turut terdampak pandemi, seperti terbatasnya penyelenggaraan pembelajaran, minimnya kesempatan untuk saling berinteraksi secara langsung dengan warga belajar dan lain sebagainya. Akan tetapi hal tersebut tidak lantas menghentikan kegiatan belajarmengajar, tidak terkecuali di PKBM.

PKBM merupakan salah satu satuan pendidikan nonformal yang bergerak untuk memberdayakan masyarakat, khususnya pada aspek pendidikan. PKBM dipandang sebagai sebuah rangkaian kegiatan belajar yang membelajarkan masyarakat dalam waktu yang beragam (Septiani, 2015). Beragamnya lapisan masyarakat memicu munculnya keberagaman kebutuhan serta keberagaman masalah, sehingga dibutuhkan rangkaian solusi untuk memenuhi kebutuhan serta menanggulangi permasalahan yang muncul. Oleh sebab itu PKBM Mentari hadir sebagai wadah untuk memenuhi kebutuhan masyarakat yang variatif berikut juga sebagai pihak yang menawarkan solusi terkait permasalahan yang melanda masyarakat tersebut.

Penyelenggaraan pendidikan nonformal tidaklah mudah. Selalu ada hambatan yang hadir dan menyulitkan proses penyelenggaraan pendidikan tersebut. Hambatan tersebut selalu hadir dari berbagai pihak, baik dari internal lembaga nonformal, pihak 
pemangku jabatan sebagai yang berwenang terkait kebijakan, bahkan masyarakat sebagai warga belajar dan mitra utama dalam penyelenggaraan program pendidikan nonformal. Oleh sebab itu daya tahan dalam menghadapi berbagai hambatan dan kesulitan sangat perlu dikuasai oleh seorang praktisi pendidikan nonformal.

Ketahanmalangan atau adversity quotient didefinisikan sebagai rencana yang dirancang untuk mengukur kemampuan serta gaya individu dalam memberikan respon terhadap situasi yang berat (Nikam dan Uplane 2013). Ketahanmalangan juga disebut sebagai kemampuan individu dalam menghadapi rintangan dan menjadikannya peluang untuk mencapai keberhasilan yang diimpikan (Dewi dan Suhendri, 2017). Selain itu, ketahanmalangan juga dapat diartikan sebagai kecerdasan seseorang untuk berkembang melalui rintangan serta tantangan dalam kehidupan supaya dapat menjadi pribadi yang lebih baik (Yudana dan Dantes, 2013). Kemampuan seseorang dalam bertahan di tengah badai hambatan yang menghadang menjadi ciri khusus dari definisi ketahanmalangan.(Nikam \& Uplane, 2013).

Ketahanmalangan terdiri atas empat komponen penting yakni kontrol, kepemilikan, jangkauan serta daya tahan (Nikam dan Uplane, 2013). Dapat diartikan bahwa ketahanmalangan seseorang dapat diukur melalui empat komponen tersebut. Komponen pertama yakni kontrol, yang dimaksudkan untuk mengukur sebesar apa kemampuan individu untuk mengontrol diri serta perasaannya dalam merespon kesulitan yang dialami. Komponen kedua yakni kepemilikan, untuk mengukur apakah individu tersebut memiliki tanggung jawab untuk menghadapi kesulitan tersebut. Komponen ketiga yakni jangkauan dimaksudkan untuk mengukur sejauh mana individu tersebut dapat menjangkau kesulitan-kesulitan yang akan menghadang jalan kesuksesannya. Komponen keempat yakni daya tahan, yang ditujukan untuk mengukur seberapa kuat induvidu tersebut bertahan dalam kesulitan tersebut.

PKBM sebagai salah satu wadah pendidikan yang diperuntukkan memenuhi kebutuhan masyarakat menjadi bagian penting yang memerlukan daya ketahanmalangan pengelola yang kuat. Ketahanmalangan harus mendarah daging dalam diri seorang pengelola PKBM dengan menguasai keempat komponen ketahanmalangan. Pengelola PKBM harus memiliki kemampuan dalam mengontrol reaksi sebagai respon atas kesulitan-kesulitan yang menghadang penyelenggaraan kegiatan pembelajaran. Hal ini dapat dimanfaatkan ketika menghadapi berbagai macam penolakan baik dari masyarakat sebagai calon warga belajar, atau tekanan dari pemerintah setempat, maupun pihak-pihak yang terlibat dalam penyelenggaraan kegiatan belajar-mengajar di PKBM.

Pengelola juga diharapkan mampu mengukur jangkauan atas dampak yang akan dimunculkan oleh kesulitan tersebut. Misalnya sejauhmana kesulitan tersebut akan mempengaruhi operasional pembelajaran, aspek mana saja yang kira-kira akan terdampak, dan lain sebagainya. Kemudian seorang pengelola PKBM Mentari juga patut untuk memperhatikan capaian atas jangkauan yang diperkirakan terdampak dari kesulitan tersebut.

Komponen terakhir yang bisa dikatakan sebagai komponen paling penting dalam ketahanmalangan adalah komponen endurance, yang dimaksudkan untuk mengukur seberapa kuat seorang pengelola bertahan dan menghadapi kesulitan, sehingga mampu mengubah hambatan-hambatan tersebut menjadi sebuah peluang. Komponen ini dapat diterapkan dalam menghadapi berbagai kesulitan, seperti halnya dalam kesulitan di tengah mewabahnya pandemi covid-19, pengelola PKBM dituntut untuk bertahan dalam 
pembatasan sosial berskala besar, menurunnya penghasilan, dan lain sebagainya supaya kemudian mampu merubah kesulitan tersebut menjadi peluang dengan menyediakan kegiatan pembelajaran yang dapat memenuhi kebutuhan dan diminati oleh masyarakat.

Ketahanmalangan bisa dikatakan identik dengan kesulitan yang kemudian memicu munculnya keharusan seseorang untuk bertahan menghadapi kesulitan tersebut. Kesulitan (adversity) sendiri memiliki setidaknya tiga tingkatan, yakni kesulitan sosial, kesulitan di tempat kerja dan kesulitan individu (Lanka et al., 2012). Pada dasarnya kesulitan berawal dari adanya perubahan di tengah peradaban manusia. Mulai dari perubahan pola pikir dalam memandang suatu permasalahan, kemudian perubahan sikap dalam merespon permasalahan yang terjadi berdasarkan pada berubahnya cara pandang masyarakat, kemudian perubahan kebiasaan yang terjadi di masyarakat. Perubahan-perubahan ini kemudian memicu munculnya berbagai kesenjangan sosial yang menjadi kesulitan sosial di masyarakat. Kemudian kesulitan meningkat pada tingkatan kesulitan di lapangan pekerjaan. Hal ini disebabkan oleh perubahan yang memunculkan situasi serta kondisi yang identik dengan kompetisi yang mengharuskan setiap orang untuk memiliki daya saing tinggi. Setiap orang akan memiliki tuntutan dalam pekerjaannya, sehingga mereka berusaha untuk memenuhi tuntutan-tuntutan tersebut demi bertahan dan memperoleh hasil terbaik dari pekerjaan mereka. Kesulitan-kesulitan inilah yang kemudian menjadi beban individu untuk menyesuaikan diri berikut juga bertahan dalam menghadapi kesulitankesulitan tersebut dan munculah tingkat teratas dari kesulitan yakni kesulitan individu. Berawal dari kesulitan sosial kemudian berdampak pada kesulitan di lapangan pekerjaan dan akhirnya menjadi kesulitan individu. Beginilah kesulitan (adversity) berkembang tahap demi tahap.

Selaras dengan kesulitan yang dihadapi oleh hampir seluruh pengelola PKBM. Sebagai lembaga yang menyediakan pembelajaran sesuai dengan kebutuhan masyarakat, PKBM dituntut untuk selalu siap dengan berbagai perubahan yang terjadi dimasyarakat. Mengingat masyarakat merupakan kumpulan makhluk hidup yang terus mengalami perubahan, maka bisa dipastikan bahwa masyarakat tidak akan pasif pada suatu masa melainkan akan berkembang dan berubah secara terus-menerus seiring berjalannya waktu dan berkembangnya zaman. (Yudiana \& Wahyudiono, 2020) Perubahan yang terjadi di masyarakat menjadi sebuah tantangan utama bagi PKBM. Belum lagi apabila timbul penolakan dari golongan kecil masyarakat yang kurang terbuka pada perubahan, mengingat setiap perubahan pasti akan diterima dan ditolak oleh masyarakat yang mengharuskan pengelola PKBM untuk meyakinkan golongan masyarakat supaya berkenan dalam menerima perubahan dan dapat turut berpartisipasi dalam mengembangkan perubahan tersebut. Selanjutnya, perubahan-perubahan juga dapat hadir dari lingkup kedinasan terkait pihak yang berwenang, seperti perubahan kebijakan pemerintah mengenai pembelajaran di lembaga nonformal, kebijakan mengenai pembiayaan pendidikan nonformal, dan lain sebagainnya yang dapat disebut sebagai kesulitan di lapangan.(Yoyon Suryono and Entoh Tohani, 2016). Hal-hal tersebutlah yang kemudian mendatangkan tantangan bagi individu khususnya pengelola PKBM dan kemudian mengharuskan pengelola PKBM untuk selektif dan terampil dalam menghadapi tantangan tersebut.

Mayoritas warga belajar di PKBM merupakan orang dewasa yang telah memiliki pengalaman hidup serta konsep diri yang matang, maka kegiatan pembelajaran tidak dapat diselenggarakan seperti pada pembelajaran formal. Kegiatan pembelajaran orang dewasa 
(andragogi) tidak dapat dibatasi dengan aturan-aturan yang mengekang seperti yang diterapkan pada pembelajaran paedagogi. Pembelajaran andragogi memandang pengalaman warga belajar sebagai salah satu sumber belajar utama yang penting untuk dilibatkan dalam proses pembelajaran. Hal ini menjadi salah satu kelebihan pendidikan nonformal, akan tetapi disisi kelebihan, pasti terdapat kesulitan atau tantangan yang harus dilewati. Tantangan dalam pembelajaran andragogi adalah adanya keberagaman. Salah satunya adalah keberagaman dari latar belakang warga belajar yang berbeda sehingga memicu adanya pengalaman hidup yang sangat berbeda pula. Oleh sebab itu, pembelajaran tidak dapat disama ratakan antara satu warga belajar dengan warga belajar yang lainnya. Sebagai ranah pendidikan yang menawarkan solusi atas keresahan mayarakat atas pendidikan, maka kegiatan pembelajaran pada ranah nonformal perlu diselenggarakan dengan mempertimbangkan strategi ketahanmalangan pengelola untuk dapat menghadapi berbagai tantangan yang pasti akan muncul.

Strategi yang pertama fleksibilitas pengelolaan kelas terutama dalam aspek waktu, yakni dengan memperhatikan waktu luang warga belajar. Pengelolaan kelas dipandang sebagai sebuah ide untuk menciptakan suasana kelas yang kondusif demi menunjang efektivitas pembelajaran (Ghofar, 2017). Pengelolaan kelas perlu dipertimbangkan secara matang untuk menghindari pembelajaran yang monoton dan membosankan. Apalagi dalam aspek waktu penyelenggaraan pembelajaran yang perlu disesuaikan dengan waktu luang masyarakat sebagai warga belajar. Hal ini ditujukan supaya warga belajar nyaman dalam mengikuti pembelajaran dan tidak mengganggu pekerjaan ataupun kegiatan seharihari. Seperti halnya pembelajaran di PKBM Mentari yang dilaksanakan seminggu sekali dan diselenggarakan pada malam hari yang merupakan waktu senggang bagi para warga belajar. Hal ini memungkinkan warga belajar dapat tetap belajar sebagaimana mestinya tanpa menganggu pekerjaan mereka di siang hari.

Strategi yang kedua adalah fleksibilitas biaya juga dapat dijadikan sebagai salah satu dari strategi ketahanmalangan yang dapat diterapkan oleh pengelola PKBM. Walaupun biaya merupakan salah satu hal utama yang diperlukan dalam operasional pendidikan khususnya di PKBM, akan tetapi pengelola harus dapat mewujudkan fleksibilitas biaya bagi warga belajar mengingat mayoritas warga belajar memiliki penghasilan yang menengah ke bawah. Misalnya seperti yang diterapkan di PKBM Mentari dalam program kesetaraan paket B yang mematok biaya sebesar Rp.1.750.000. Pengelola memberikan fleksibilitas kepada warga belajar untuk tidak membayar uang pendidikan sekaligus di muka, melainkan warga belajar dapat mengangsur pembayaran biaya pendidikan tersebut selama megikuti program paket B. Hal ini dapat membantu meringankan beban warga belajar dari segi pembayaran. Untuk menutupi biaya operasional yang belum dibayarkan, ditambah dengan kebijakan baru yang menentukan bahwa warga diluar usia sekolah sudah tidak lagi mendapatkan bantuan operasional pendidikan (BOP) maka kecerdasan serta keuletan pengelola sangat diperlukan dalam mengajukan berbagai proposal demi memenuhi pembiayaan yang diperlukan.

Strategi yang ketiga adalah penguatan kemitraan dengan masyarakat. Kemitraan merupakan sebuah tanggung jawab sosial yang melibatkan beberapa pihak dengan tujuan pemberdayaan. Kemitraan diselenggarakan dengan membangun hubungan interaktif yang berdasarkan pada komunikasi yang saling menguntungkan (Astuti et al., 2020). Komunikasi dalam kemitraan terdiri atas tiga arah komunikasi, yakni komunikasi ke atas, ke bawah dan horizontal, yang kemudian mendorong adanya kompromi yang saling 
menguntungkan (Lestari et al., 2015). Komunikasi yang diharapkan adalah komunikasi terarah, baik komunikasi dari atas yang berarti komunikasi dari pimpinan tetap tidak mengesampingkan komunikasi dari bawah yang berarti suara serta pendapat para anggota masyarakat sehingga muncul komunikasi horizontal yang mewadahi pendapat setiap orang. Oleh sebab itu, maka dapat disimpulkan bahwa dasar dari kemitraan merupakan adanya komunikasi serta interaksi. Hubungan kemitraan PKBM dengan masyarakat merupakan nyawa utama keberlangsungan kegiatan pembelajaran di PKBM, karena setiap program diselenggarakan dengan melibatkan masyarakat. Kemitraan ini dapat dibangun dengan menghadirkan suasana yang rukun dan harmonis dengan membangun komunikasi dua arah yang saling melengkapi, memenuhi kebutuhan belajar masyarakat tanpa menggurui, memberikan bahan ajar yang sesuai dengan kebutuhan serta minat masyarakat, menerima berbagai masukan, saran dan kritik dengan baik, dan lain sebagainya. Hal ini dimaksudkan untuk memperluas jaringan PKBM dan meningkatkan branding PKBM. Promosi terbaik dan tercepat di masyarakat adalah dari mulut ke mulut. Hubungan yang terjalin dengan baik bersama masyarakat, akan mendorong masyarakat untuk mempromosikan PKBM secara sukarela dengan membicarakan hal-hal positif yang kemudian dapat mempengaruhi keingintahuan masyarakat lain mengenai kegiatan pembelajaran di PKBM berdasarkan citra yang terbangun di tengah masyarakat. Citra yang baik maka akan memungkinkan para warga belajar atau bahkan alumni untuk merekomendasikan PKBM kepada kerabat maupun kenalan-kenalan yang memerlukan jasa PKBM dalam hal pembelajaran, sehingga jangkauan PKBM akan semakin luas. Hal inilah yang diperoleh dengan membangun ikatan positif dengan masyarakat.

Strategi yang keempat adalah penguatan kemitraan dengan perangkat desa serta pihak-pihak berwenang. Penyelenggaraan berbagai kegiatan tentu saja perlu mendapatkan izin dari perangkat desa serta pihak-pihak yang berwenang di daerah setempat, seperti apparat keamanan, dinas pendidikan dan kebudayaan setempat. Penguatan kemitraan dengan perangkat desa serta pihak-pihak yang berwenang dimaksudkan untuk mempermudah proses perizinan penyelenggaraan kegiatan pembelajaran. Kemitraan ini dapat dibangun dengan memaksimalkan sinergi bersama perangkat desa serta pihak-pihak yang berwenang dan melibatkan mereka dalam penyelenggaraan berbagai kegiatan. Hal ini dimaksudkan untuk menghargai keberadaan perangkat desa serta pihak-pihak yang berwenang, karena perangkat desa serta pihak-pihak yang berwenang juga memiliki tanggung jawab untuk memberdayakan masyarakat serta memenuhi kebutuhan masyarakat, termasuk dalam aspek pendidikan. Oleh sebab itu perangkat desa serta pihakpihak yang berwenang menjadi pihak yang penting untuk turut dilibatkan dalam penyelenggaraan program pembelajaran. Ketika ada sikap saling menghargai, maka toleransipun akan muncul dan mempermudah proses penyelenggaraan pembelajaran sebagai salah satu solusi di tengah situasi yang mungkin menyulitkan berbagai pihak.

\section{KESIMPULAN}

Berdasarkan hasil kajian, maka dapat disimpulkan bahwa strategi ketahanmalangan yang perlu diterapkan dan dikembangkan oleh pengelola PKBM antara lain: 1) menyelenggarakan kegiatan pembelajaran secara fleksibel dalam segi waktu, sehingga tidak mengganggu kegiatan masyarakat sehari-hari; 2) menyediakan pembelajaran dengan biaya yang terjangkau supaya tidak memberatkan masyarakat dalam mengikuti pembelajaran; 3) menjadikan masyarakat sebagai mitra utama dalam 
keberlangsungan kegiatan belajar-mengajar di PKBM dan 4) membangun sinergi dengan perangkat desa setempat.

\section{DAFTAR RUJUKAN}

Agustin, M., Puspita, R. D., Nurinten, D., \& Nafiqoh, H. (2020). Tipikal Kendala Guru PAUD dalam Mengajar pada Masa Pandemi Covid 19 dan Implikasinya. Jurnal Obsesi : Jurnal Pendidikan Anak Usia Dini, 5(1), 334. https://doi.org/10.31004/obsesi.v5i1.598

Apriyanti, C., \& Widoyoko, R. D. T. (2021). Persepsi dan Aksi Masyarakat Pedesaan di Masa Pandemi. Jurnal Ilmu Sosial Dan Humaniora, 10(1), 50-69.

Asmin, F. (2018). Konstruksi Modal Sosial Bagi Pengelolaan Hutan Berbasis Masyarakat : Sebuah Kerangka Konseptual. Jurnal Ilmu Sosial Dan Humaniora, 7(1), 32-45.

Astuti, Y. P., Zuhriya, R., Pratiwi, B., Komunikasi, J., \& Iain, I. (2020). Community Relations UPT Taman Balekambang Surakarta dalam Program Pengembangan Kemitraan Masyarakat ( Community Relations UPT Taman Balekambang Surakarta in the Development Program Community Partnership ) bawah Kepala Dinas Pariwisata Kota Masyarakat dala. Profetik Jurnal Komunikasi, 12(2), 333353.

Dewi, M., \& Suhendri, H. (2017). Pengaruh Kemandirian dan Ketahan malangan (Adversity Quotient) terhadap Kemampuan Pemecahan Masalah Matematika. Jurnal Intraksi, 2(3), 724-735.

Ghofar, A. (2017). Fleksibilitas Pengelolaan Kelas dalam Pendidikan (Ekspektasi Efektivitas Keberhasilan Proses Pembelajaran). Al-Tarbawi Al-Haditsah : Jurnal Pendidikan Islam, 2(1), 24-42. https://doi.org/10.24235/tarbawi.v2i1.2025

Hesti Ratna Juwita., Roemintoyo, B. U. (2020). The Role of Adversity Quotient in the Field of Education: A Review of the Literature on Educational Development. International Journal of Educational Methodology, 6(3), 507-515. https://doi.org/10.12973/ijem.6.3.507

Lanka, S., Vithana, K. G., \& Kingdom, U. (2012). Is Outward Bound Training ( OBT ) An Effective Tool for Human Resource Development ( HRD )? A Case Study from Sri Lanka. International Journal of Contempory Business Studies, 3(4), 42-50.

Lestari, R. B., Nulhaqim, S. A., \& Irfan, M. (2015). Teamwork Pengembangan Kemitraan (Studi Kasus Kelompok Kerja Pengembangan Kemitraan dalam Penangulangan Kemiskinan di Kota Bogor). EMPATI: Jurnal Ilmu Kesejahteraan Sosial, 4(1), 1-21. https://doi.org/10.15408/empati.v4i1.9763

Mochammad Syamsuddin, Kuswara, Harris Iskandar, \& Ade Kusmiadi. (2015). Sejarah Direktorat Jenderal Pendidikan Anak Usia Dini dan Pendidikan Masyarakat.

Nikam, V. B., \& Uplane, M. M. (2013). Adversity Quotient and Defense Mechanism of Secondary School Students. Universal Journal of Educational Research, 1(4), 303-308. https://doi.org/10.13189/ujer.2013.010405

Perbawa, I. K. S. L. P. (2021). KEBIJAKAN PEMERINTAH INDONESIA DALAM MENANGGULANGI COVID-19 BERDASARKAN INSTRUMEN HUKUM INTERNASIONAL. Jurnal Ilmu Sosial Dan Humaniora, 10(1), 197-205.

Septiani, M. (2015). Pengalaman Pusat Kegiatan Belajar Masyarakat (Pkbm) Dalam Memfasilitasi Masyarakat Belajar Sepanjang Hayat. Jurnal Ilmiah Visi, 10(2), 67- 
76.

Yoyon Suryono and Entoh Tohani. (2016). Inovasi Pendidikan Nonformal.

Yudana, M., \& Dr. Gede Rasben Dantes, S. (2013). Kontribusi Motivasi Berprestasi, Disiplin Kerja, Dan Ketahanmalangan (Adversity Quotient) Terhadap Kinerja Profesional Guru Sma Negeri Di Kecamatan Karangasem Kabupaten Karangasem Bali. Jurnal Administrasi Pendidikan, 4(1), 1-13.

Yudiana, I. K., \& Wahyudiono, A. (2020). Pengembangan Desa Wisata Berbasis Multikultural Di Desa Patoman. Jurnal Ilmu Sosial Dan Humaniora, 9(2), 308. https://doi.org/10.23887/jish-undiksha.v9i2.22358 
AKSARA: Jurnal Ilmu Pendidikan Nonformal

P-ISSN 2407-8018 E-ISSN 2721-7310 DOI prefix 10.37905

Volume 07, Issue 03 September 2021

http://ejurnal.pps.ung.ac.id/index.php/Aksara 